\title{
FinAL AUDIT REPORT OF Remedial Action Construction AT THE UMTRA PROJECT Ambrosia LaKe, New Mexico, Site
}

\section{September 1995}

\section{DISCLAIMER}

This report was prepared as an account of work sponsored by an agency of the United States Government. Neither the United States Government nor any agency thereof, nor any of their employees, makes any warranty, express or implied, or assumes any legal liability or responsibility for the accuracy, completeness, or usefulness of any information, apparatus, product, or process disclosed, or represents that its use would not infringe privately owned rights. Reference herein to any specific commercial product, process, or service by trade name, trademark, manufacturer, or otherwise does not necessarily constitute or imply its endorsement, recommendation, or favoring by the United States Government or any agency thereof. The views and opinions of authors expressed herein do not necessarily state or reflect those of the United States Government or any agency thereof. 


\section{DISCLAIMER}

Portions of this document may be illegible in electronic image products. Images are produced from the best available original document. 
REV. 0

FINAL AUDIT REPORT OF REMEDIAL ACTION CONSTRUCTION AT THE UMTRA PROJECT AMBROSIA LAKE, NEW MEXICO, SITE

September 1995

Prepared for

U.S. Department of Energy

Environmental Restoration Division

UMTRA Project Team

Albuquerque, New Mexico

Prepared by

Jacobs Engineering Group Inc.

Albuquerque, New Mexico 
The final audit report for remedial action at the Ambrosia Lake, New Mexico, Uranium Mill Tailings Remedial Action (UMTRA) Project site consists of a summary of the radiological surveillances/audits, quality assurance $(Q A)$ in-process surveillances, and a $Q A$ final closeout inspection performed by the U.S. Department of Energy (DOE) and the Technical Assistance Contractor (TAC).

One radiological surveillance and three radiological audits were performed at the Ambrosia Lake site. The surveillance was performed on 12-16 April 1993 (DOE, 1993d). The audits were performed on 26-29 July 1993 (DOE, 1993b); 21-23 March 1994 (DOE, 1994d); and 1-2 August 1994 (DOE, 1994d). The surveillance and audits resulted in 47 observations. Twelve of the observations raised DOE concerns that were resolved on site or through subsequent corrective action. All outstanding issues were satisfactorily closed out on 28 December 1994. The radiological surveillance and audits are discussed in Section 2.0 of this report.

A total of seven QA in-process surveillances were performed at the Ambrosia Lake UMTRA site. These were performed on 7-8 June 1993 (DOE, 1993c); 9-10 September 1993 (DOE, 1993a); 6-7 April 1994 (DOE, 1994c); $12-13$ July 1994 (DOE, 1994b); $18-19$ August 1994 (DOE, 1994a); 24 January 1995 (DOE, 1995c); and 13-14 April 1995 (DOE, 1995b). The surveillances resulted in 108 observations. Fifteen observations contained recommendations that required responses from the Remedial Action Contractor (RAC). One observation contained a recommendation that required no response. All outstanding issues were satisfactorily closed by the RAC and the DOE. The QA in-process surveillances are discussed in Section 3.0 of this report.

The DOE/TAC Ambrosia Lake final remedial action close-out inspection was conducted on 26 July 1995 (DOE, 1995a). This inspection cited 13 items from the RAC's punch list that needed to be completed before the inspection report could be closed. MK-Ferguson responded to the 13 open items on 8 September 1995. The DOE concurred with their responses and closed the close-out inspection on 14 September 1995.

Other audits such as on-site construction reviews performed by the U.S. Nuclear Regulatory Commission were not performed at the Ambrosia Lake site.

To summarize, a total of 155 observations were noted during DOE/TAC audit and surveillance activities. Follow-up to responses required from the RAC for the DOE/TAC surveillance and audit observations indicated that all issues related to the Ambrosia Lake site were resolved and closed to the satisfaction of the DOE.

All audit and surveillance observations and recommendations have been closed out to the DOE's satisfaction. Therefore, this final audit report segment of the site certification process is complete. 


\section{TABLE OF CONTENTS}

Section

Page

EXECUTIVE SUMMARY ES-1

1.0 INTRODUCTION................................................................................ 1 1

1.1 Radiological surveillances......................................................... 1-1

1.2 Quality assurance in-process surveillances ........................................ 1-1

1.3 Remedial action close-out inspection ................................................ 1-1

1.4 Other quality assurance audits/surveillances..................................... 1-1

1.5 Audit procedures................................................................... $1-3$

1.6 General standards ................................................................. $1-3$

2.0 RADIOLOGICAL SURVEILLANCES ................................................ $2-1$

2.1 Surveillance/audit objectives ....................................................... $2-1$

2.2 Surveillance/audit results ......................................................... 2 2-2

2.3 Summary and conclusions.......................................................

3.0 QUALITY ASSURANCE IN-PROCESS SURVEILLANCES ............................ $3-1$

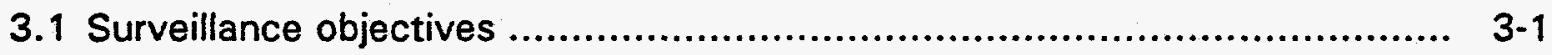

3.2 Surveillance results ........................................................... $3-1$

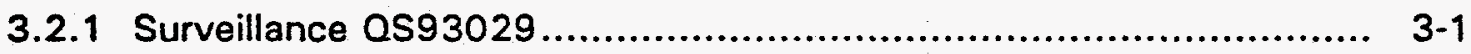

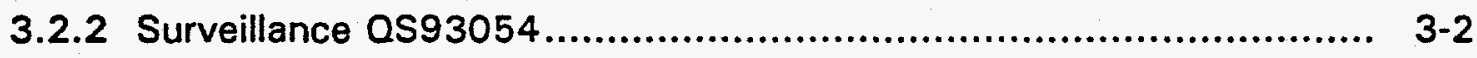

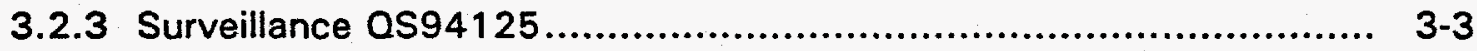

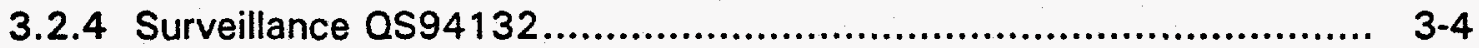

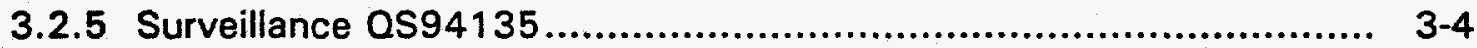

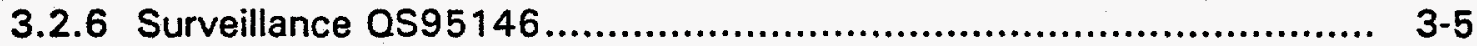

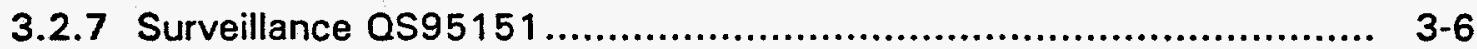

3.3 Summary and conclusions................................................... 3

4.0 REMEDIAL ACTION CLOSE-OUT INSPECTION........................................ 4-1

4.1 Remedial action close-out inspection objectives................................ 4-1

4.2 Remedial action close-out inspection results.................................... 4-1

4.3 Summary and conclusions......................................................... $4-4$

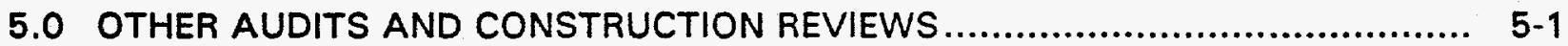

5.1 On-site construction review objectives ........................................ $5-1$

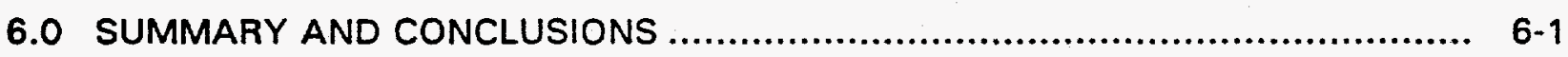

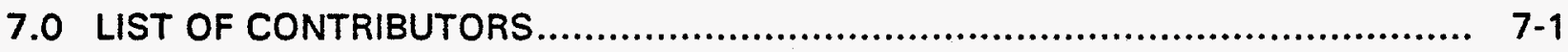

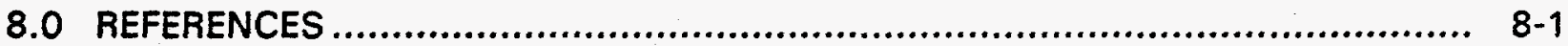


FINAL AUDIT REPORT OF REMEDIAL ACTION CONSTRUCTION

AT THE UMTRA PROJECT AMBROSIA LAKE, NEW MEXICO, SITE

LIST OF TABLES

\section{LIST OF TABLES}

Table

Page

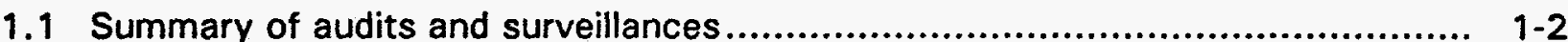




\section{LIST OF ACRONYMS}

Acronym

DOE

ERD

EPA

HP

NRC

OCS

OSCR

OA

OC

RAC

RAIP

RAP

RTRAK

TAC

UMTRA

\section{Definition}

U.S. Department of Energy

Environmental Restoration Division

U.S. Environmental Protection Agency

health physics

U.S. Nuclear Regulatory Commission

opposed crystal

on-site construction review

quality assurance

quality control

Remedial Action Contractor

remedial action inspection plan

remedial action plan

radiation tracking system

Technical Assistance Contractor

Uranium Mill Tailings Remedial Action 


\subsection{INTRODUCTION}

The final audit report provides an independent assessment by the U.S. Department of Energy (DOE) and Technical Assistance Contractor (TAC) of remedial action compliance with approved plans, specifications, standards, and 40 CFR Part 192. The report refers to remedial action activities performed at the Ambrosia Lake, New Mexico, Uranium Mill Tailings Remedial Action (UMTRA) site. Remedial action construction at the Ambrosia Lake site was under the direction of the Remedial Action Contractor (RAC).

\section{$1.1 \quad$ RADIOLOGICAL SURVEILLANCES}

Radiological surveillances and audits were performed for the DOE by the TAC at the Ambrosia Lake site to provide an independent assessment that the quality of remedial action work was sufficient to ensure that the U.S. Environmental Protection Agency (EPA) standards and other site-specific health physics (HP) requirements were met. Radiological surveillances and audits complemented quality assurance (OA) surveillances, and provided assurance that the remedial action tasks were accomplished in compliance with relevant specifications and standards. Radiological surveillances and audits were conducted at a frequency of one to two times per construction season. The results of the audits and surveillances and follow-up actions are documented in Section 2.0. A summary list of the surveillances is provided in Table 1.1.

\subsection{QUALITY ASSURANCE IN-PROCESS SURVEILLANCES}

QA in-process surveillances were performed at the Ambrosia Lake site by the TAC OA department, under the direction of the DOE, to verify that the procedures and systems required by the respective QA programs were implemented during remedial action. The $Q A$ in-process surveillances were performed at the average frequency of three per year for each organization and subcontractor conducting work in support of the UMTRA Project. Section 3.0 documents results of the $Q A$ in-process surveillances and follow-up actions at the Ambrosia Lake site. Table 1.1 summarizes the $\mathrm{OA}$ in-process surveillances.

\subsection{REMEDIAL ACTION CLOSE-OUT INSPECTION}

The remedial action close-out inspection was conducted at the Ambrosia Lake site after completion of remedial action. It was conducted to verify that the site was constructed in compliance with the approved remedial action plan (RAP), construction plans and project specifications. The results of the remedial action close-out inspection are documented in Section 4.0. A summary is provided in Table 1.1.

\subsection{OTHER QUALITY ASSURANCE AUDITS/SURVEILLANCES}

Other audits or surveillances conducted at UMTRA sites include on-site construction reviews (OSCR) performed by the U.S. Nuclear Regulatory 
Table 1.1 Summary of audits and surveillances

\begin{tabular}{|c|c|c|c|}
\hline Type/Date of activity & $\begin{array}{c}\text { Number of } \\
\text { issues }\end{array}$ & $\begin{array}{c}\text { Number of } \\
\text { observations }\end{array}$ & Date closed \\
\hline \multicolumn{4}{|c|}{ DOE/TAC radiological surveillances/audits } \\
\hline $\begin{array}{l}\text { 12-16 April } 1993 \\
26-29 \text { July } 1993 \\
21-23 \text { March } 1994 \\
\text { 1-2 August } 1994\end{array}$ & $\begin{array}{l}7 \\
3 \\
1 \\
1\end{array}$ & $\begin{array}{r}18 \\
13 \\
9 \\
7\end{array}$ & $\begin{array}{l}18 \text { February } 1994 \\
18 \text { February } 1994 \\
28 \text { December } 1994 \\
28 \text { December } 1994\end{array}$ \\
\hline \multicolumn{4}{|c|}{ DOE/TAC QA in-process surveillances } \\
\hline $\begin{array}{l}\text { 7-8 June } 1993 \\
9-10 \text { September } 1993 \\
6-7 \text { April } 1994 \\
12-13 \text { July } 1994 \\
18-19 \text { August } 1994 \\
24 \text { January } 1995 \\
\text { 13-14 April } 1995\end{array}$ & $\begin{array}{l}1 \\
2 \\
3 \\
0 \\
5 \\
1 \\
4\end{array}$ & $\begin{array}{l}11 \\
10 \\
15 \\
18 \\
19 \\
19 \\
16\end{array}$ & $\begin{array}{l}16 \text { September } 1993 \\
13 \text { December } 1994 \\
8 \text { July } 1994 \\
6 \text { August } 1994 \\
25 \text { January } 1995 \\
7 \text { April } 1995 \\
8 \text { July } 1995\end{array}$ \\
\hline \multicolumn{4}{|c|}{ DOE $/ T A C$ remedial action close-out inspections } \\
\hline 26 July 1995 & 13 & 13 & 14 September 1995 \\
\hline Other audits/surveillances & N/A & $N / A$ & N/A \\
\hline
\end{tabular}


Commission (NRC). The NRC did not perform an OSCR at the Ambrosia Lake site.

\section{$1.5 \quad$ AUDIT PROCEDURES}

Criteria and procedures for conducting UMTRA Project audits and surveillances are provided in the "UMTRA Project Audit/Surveillance Program Plan," (DOE, 1988).

\subsection{GENERAL STANDARDS}

In 1978, the U.S. Congress passed Public Law 95-604, the Uranium Mill Tailings Radiation Control Act (42 USC $\$ 7901$ et seq.), declaring uranium mill tailings a potential health hazard to the public, and requiring that certain sites be designated for remedial action. The Ambrosia Lake site was included as one of twenty-four sites. The EPA was directed to promulgate radiological and nonradiological standards for decontamination of the sites. The DOE was authorized to initiate and manage the remedial actions. The NRC was charged with concurring in the remedial actions and licensing the disposal sites. The standards that apply to all UMTRA Project sites, as promulgated by the EPA, are given in Subparts $A$ and $B$ of 40 CFR Part 192:

- The standards in Subpart A are directed at controlling the stabilization of radioactive materials at the designated disposal sites and are addressed by the engineering design specifications developed by the DOE Environmental Restoration Division (ERD) UMTRA Project for the disposal sites.

- The standards in Subpart B define the conditions under which a site was adequately cleaned up.

The processing site will be evaluated to determine if ground water restoration in accordance with Subpart B of the ground water protection standards $160 \mathrm{FR}$ 2854 ) is required. Ground water restoration, if determined necessary, will be accomplished under the UMTRA Ground Water Project. 


\subsection{RADIOLOGICAL SURVEILLANCES}

One comprehensive radiological surveillance and three comprehensive radiological audits were performed by the TAC with the DOE at the Ambrosia Lake UMTRA site. The radiological surveillance and audit provided an independent assessment that the quality of remedial action work was sufficient to ensure compliance with EPA standards and DOE Orders. The radiological surveillance and audits included but were not limited to a comprehensive review of the RAC's radiological/HP procedures, instrument calibration records, data management, personnel monitoring, and operational performance of the contractors and subcontractors responsible for HP remedial action work at the former uranium ore processing site and the uranium tailings disposal cell.

The following sections provide additional information regarding the radiological surveillance and audit activities and resolutions.

\subsection{SURVEILLANCE/AUDIT OBJECTIVES}

The TAC radiological audit program of 1995 has evolved considerably since the audits and surveillance were first performed in 1993. The process involves a complete inventory of office and site radiological conditions at the time of the audit or surveillance. The findings, observations, and recommendations are used to identify site-specific and programmatic conditions. This information is then used to identify positive attributes and address deficiencies to improve the overall radiological controls at the site and other sites encountering similar situations.

The discussion information used to determine compliance with applicable procedures and requirements were obtained from interviewing the RAC's field personnel, reviewing office activities, and touring field facilities. Reviewing applicable records and documentation provide additional verification of HP activities.

Radiological audits and surveillances have three distinct objectives. The first objective is to verify that remedial actions are meeting the EPA cleanup standards or other cleanup standards specified in the remedial action planning documents. The second objective is to evaluate control methods used by the RAC to prevent overexcavation of areas, which also avoids increased quantities of material for disposal and potential escalated remediation costs. The final objective is to review the general data management methods and procedures of the RAC, and provide a pathway for the exchange of ideas for technological improvements in the program.

Findings and observations presented in a radiological audit or surveillance could include but are not limited to the following criteria: 
- Noncompliance with requirements of the site RAP, vicinity property management and implementation manual, engineering design, or UMTRA Project directives applicable to the site.

- Evidence that the existing radiological measurement methods may result in residual contamination levels in excess of established limits (underexcavation).

- Evidence that the existing radiological measurement methods may result in the removal of materials not contaminated in excess of the limits (overexcavation). The soil contamination limits are those specified by EPA standards, including site-specific modifications agreed to by the NRC or mandated by DOE ERD directives.

- Evidence that some aspects of the contractor's radiological survey plans and procedures, measurement techniques, or data management capabilities are insufficient to allow eventual certification of the site.

- Evidence that activities are not in compliance with applicable DOE Orders.

Observations are comments considered appropriate by the auditors to document topics of concern to the DOE, and to note improvements in techniques or procedures to noncritical areas. Comments on proficiency, favorable comparisons or developmental activities may be included as observations.

\subsection{SURVEILLANCE/AUDIT RESULTS}

The information contained in this section was obtained from the final surveillance and audit reports and supporting documentation. The resolution of a finding or observation, if not obtained via a report or cover letter, was evaluated and closed based on documented information from the members of the surveillance or audit team, and/or follow-up site surveillances or audits.

2.2.1 The comprehensive site radiological surveillance (AMB-SO1) was performed by the TAC for the DOE in Ambrosia Lake, New Mexico, on 12-16 April 1993 (DOE, 1993b). Representatives from the TAC included James M. Hylko and J.B. Baird, Jr. The DOE was represented by Robert E. Cornish. On the site, RAC personnel participating in the surveillance included Bill Gallagher, Belinda Icenhower, and Ryan Holyoak. The focus of this surveillance included reviews of the RAC's procedures regarding radiological storage areas, training records, bioassay, the opposed crystal system (OCS), soil verification, personnel monitoring, daily performance logs of smear counters and friskers, capital/operating equipment, contamination control, signature the traceability, radiological postings and surveys, workplace monitoring and exposure control, occupational and visitor orientation, site-specific programmatic requirements, and the UMTRA instrumentation program. Ten site-specific observations and five programmatic observations were identified, none of which impacted the 
ability of the RAC to ensure compliance with EPA standards. In addition, three good practice observations were also identified during the surveillance. The overall conclusion from the surveillance was that radiological program requirements of the Ambrosia Lake. New Mexico remedial action program are being satisfied according to written procedures and documentation requirements.

The following observations were made during the surveillance.

Site-specific observations:

- AMB-S01-001 - Miscellaneous items were stored on shelves located in a radiologically controlled area.

- AMB-S01-002 - The training records were reviewed and determined to be in compliance with procedural requirements. Typographical errors and minor inconsistencies were identified, and resolved by site HP staff.

- AMB-S01-003 - The bioassay program was reviewed and determined to be in compliance with procedural requirements. Minor inconsistencies were identified and resolved by site HP staff.

- AMB-S01-004 - The OCS and soil verification sampling were reviewed and determined to be in compliance with procedural requirements.

- AMB-S01-005 - Records and worksheets related to personnel monitoring were reviewed and determined to be in compliance with existing requirements.

- AMB-S01-006 - The daily performance logs of alpha smear counters, beta/gamma smear counters, and friskers located at access control were reviewed for consistency and completeness, and determined to be in compliance with existing requirements.

- AMB-S01-007 - External dose rate monitoring, contamination control related to heavy equipment, and radiation detection equipment calibrations were reviewed for consistency and completeness, and determined to be in compliance with existing requirements.

- AMB-S01-008 - The capital/operating equipment list was reviewed and determined to be in compliance with procedural requirements.

- AMB-S01-009 - Site contamination control requirements were reviewed and determined to be in compliance with procedural requirements. 
- AMB-S01-010 - The radiological postings around the perimeter of the Ambrosia Lake UMTRA site were reviewed and determined to be in compliance with procedural requirements.

Good practice observations:

- AMB-S01-011 - A memo to D. Carlson dated 24 February 1993 provides the traceability of HP personnel to their corresponding initials and signatures.

- AMB-S01-012 - Site HP personnel used pictures of the vehicles to perform surveys instead of relying on drawings that do not provide adequate detail, and may result in bypassing areas of the vehicle that may accumulate contamination.

- AMB-S01-013 - A fraction rule worksheet was developed that summarizes input data for performing the fraction rule calculation.

Programmatic observations:

- AMB-S01-014-Occupational worker and visitor orientation was reviewed and determined to be in compliance with procedural requirements. Minor discrepancies were identified and reported to site HP personnel.

- AMB-S01-015 - Site-specific and procedural inconsistencies were identified in RP-002-1, Rev. 2 and RAC-RP-002, Rev. 1. These inconsistencies were reported to site HP personnel.

- AMB-S01-016 - Site-specific and procedural inconsistencies were identified in RAC-IN-001, Rev. 0,ICN-01. These inconsistencies were reported to site HP personnel.

- AMB-S01-017 - Site-specific and procedural inconsistencies were noted in RAC-IN-001, Rev. 0, ICN-01, and RP-002-1, Rev. 2, regarding the collection and display of data from computer programs, including the use of computer printouts in lieu of procedural attachments. This information was reported to site HP personnel.

- AMB-S01-018 - Minor inconsistencies in the proper identification of units were identified in the soil verification data printout. These inconsistencies were reported to site HP personnel.

In a letter dated 18 February 1994 (from Robert E. Cornish to Robert E. Lawrence, reference UMT/RAC10294-0028), the UMTRA Project Office deemed the corrective actions acceptable, thereby closing this surveillance. 
2.2.2 The first comprehensive site radiological audit (AMB-A02) was performed by the TAC for the DOE in Ambrosia Lake, New Mexico, on 26-29 July 1993 (DOE, 1993b). Representatives from the TAC included James M. Hylko and William R. James. The DOE was represented by Robert E. Cornish. On the site, RAC personnel participating in the audit included Bill Gallagher, Belinda Icenhower, and Ryan Holyoak. The focus of this audit included the review of the radiological procedures and measurements regarding access control, air sampling, respiratory protection, excavation control, contamination control, training, verification soil sampling, monitoring external dose rates, OCS analytical performance, QA control, and data management and analysis. Eight site-specific observations and two programmatic observations were identified, none of which impacted the ability of the RAC to ensure compliance with EPA standards. In addition, three good practice observations were also identified during the audit. The overall conclusion from the audit was that the radiological aspects of the Ambrosia Lake. New Mexico remedial action program are being performed effectively according to written procedures and documentation requirements.

The following observations were made during the surveillance.

Site-specific observations:

- $A M B-A 02-001$ - Excavation control methods were reviewed and are in compliance with existing procedures, which should minimize both overexcavation and underexcavation.

- $A M B-A 02-002$ - Verification soil sampling was reviewed and determined to be in compliance with existing procedures.

- $\quad$ AMB-A02-003 - Site OCS operations were observed to be conducted in accordance with existing procedures. The radium-226 analytical performance on blind quality control $(Q C)$ samples demonstrated the ability to meet accuracy requirements at the 95 percent confidence level of \pm 30 percent for individual results and \pm 10 percent for group data.

- $\quad$ AMB-A02-004 - Occupational radiation protection program areas of air sampling, external dose-rate monitoring, contamination control, and access control were reviewed and determined to be managed appropriately and in compliance with existing procedures.

- AMB-A02-005 - Adherence to various components of the RAP was reviewed and determined to be in compliance.

- $\quad$ AMB-A02-006 - Pursuant to a request by the DOE, the auditors followed up on solidified sludge disposal and determined that the site is in compliance with applicable requirements. 
- $A M B-A 02-007$ - Smears and the end-roll of radiological tape still displaying the radiation symbol were found in the regular trash receptacle in the access control office.

- $A M B-A 02-008$ - Various sections of the following procedures were reviewed and determined to be in compliance with existing procedures: Environmental Monitoring for Radionuclides (RAC-RP-001, Rev. 0, ICN-01); Radon Monitoring with Alpha Track Detectors (RP-001-1, Rev. 0); Radon Monitoring With Radon Gas Monitors (RP-001-2, Rev. 0, ICN-01); Environmental Gamma Radiation Monitoring (RP-001-3, Rev. 0, ICN-01); and Environmental Air Particulate Monitoring (RP-001-4, Rev. 1). Minor inconsistencies were brought to the attention of the site HP manager and currently are being addressed.

Good practice observations:

- AMB-A02-009 - Breathing zone air sampling for long-lived alpha emitters has been performed. During the recent period of elevated air concentrations, elevated area air samples were sent individually for isotopic analyses.

- $A M B-A 02-010$ - During a period of excessive airborne long-lived alpha concentrations, the site HP manager required consistent (several days of) lowered air concentrations before discontinuing the respirator requirement.

- $A M B-A 02-011$ - The HP technician performing unconditional release surveys of vehicles leaving the decontamination pad was observed to be very conscientious in requiring the operator to wash off all visible materials prior to taking smears.

Programmatic observations:

- $\quad A M B-A 02-012$ - Pursuant to a request by the DOE, the auditors followed up on biohazardous waste disposal and noted that two procedures inaccurately referenced sections for labeling regulated wastes. This also is in reference to Bioassay Procedure RP-004-1, Rev. 2, ICN-01.

- AMB-A02-013 - Sections of the Health Physics Monitoring Plan were performed in accordance with standard operating procedures. Although Section 1.0, Introduction, states in part that "when differences in methodology or routine good practices occur, guidance in the RAC Health Physics Procedures shall take precedence over the guidance of this Plan," the TAC has identified inconsistencies and brought them to the attention of the site HP manager. 
In a letter dated 18 February 1994 (from Robert E. Cornish to Robert E. Lawrence, reference UMT/RAC/0294-0029), the UMTRA Project Office deemed the corrective actions acceptable, thereby closing this audit.

2.2.3 The second comprehensive site radiological audit (AMB-A03) was performed by the TAC for the DOE in Ambrosia Lake, New Mexico, on 21-23 March 1994 (DOE, 1994d). James M. Hylko represented the TAC, and Robert E. Cornish represented the DOE. On the site, RAC personnel participating in the audit included Bill Gallagher and Ryan Holyoak. The focus of this audit included the review and closure of previous AMB observations, Subpart T 40 of CFR Part 61, (Radon Flux Measurements (OP-003-5, Rev. 1)), Verification Soil Sampling (OP003-1, Rev. 1, ICN-01), Sealed Radioactive Source Accountability (RAC-RP008, Rev. 1), radiation tracking system (RTRAK) Operations Procedure (RAC-RT001, Rev. O), RTRAK Startup and Shutdown (RT-001-1, Rev. O) and RTRAK Maintenance (RT-001-2, Rev. 0), Site Contamination Control (RAC-RP-003, Rev. 1), Access Control (RP-003-1, Rev. 1), Personnel Monitoring (RP-003-2, Rev. 2), and general HP requirements, and operation of the OCS. Eight site-specific observations and one programmatic observation were identified, none of which impacted the ability of the RAC to ensure compliance with EPA standards. The overall conclusion from the audit was that the radiological program requirements of the Ambrosia Lake, New Mexico remedial action program are being satisfied according to written procedures and documentation requirements. Audit issues are outlined in Section $\mathbf{5 . 1}$ of this report.

The following observations were made during the surveillance.

Site-specific Observations:

- AMB-A03-002.a - Radon flux measurement collection protocols, as reviewed, are acceptable.

- $\quad$ AMB-A03-003.a - Verification soil sampling protocols, as reviewed, are acceptable.

- $\quad$ AMB-A03-004.a - Sealed radioactive source accountability, as reviewed, is acceptable.

- $\quad$ AMB-A03-004.b - Dose rate measurements taken from source storage locations are below limits specified in RAC-RP-008, Rev. 1.

- AMB-A03-005.a - RTRAK operations, as reviewed, are acceptable.

- $\quad$ AMB-A03-005.b - Use of safety precautions during RTRAK maintenance, as reviewed, in RT-001-2, Rev. 0, ICN-01 are acceptable and consistent with other RTRAK procedures. 
- AMB-A03-006.a - Site contamination control, access control, personnel monitoring, and general HP requirements, as reviewed, are acceptable.

- AMB-A03-007.a - The OCS performance, as reviewed, is acceptable.

Programmatic Observation:

- APO/AMB-A03-001.a - Previous open observations, AMB-S01-017Recommendation 2, AMB-S01-018, AMB-A02-012, and AMB-A02-013, have been closed by the DOE.

In a letter dated 28 December 1994 (from Robert E. Cornish to Robert E. Lawrence, reference UMT/RAC/1294-0140), the UMTRA Project Office deemed the corrective actions acceptable, thereby closing this audit.

2.2.4 The third comprehensive site radiological audit (AMB-AO4) was performed by the TAC for the DOE in Ambrosia Lake, New Mexico, on 1-2 August 1994 (DOE, 1994d). James M. Hylko represented the TAC, and Robert E. Cornish represented the DOE. On the site, RAC personnel participating in the audit included Bill Gallagher and Ryan Holyoak. The focus of this audit included the review of Subpart T of 40 CFR Part 61 (NESHAP)/Radon Flux Measurements (OP-003-5, Rev. 1), RTRAK Operations Procedure (RAC-RT-001, Rev. 0), Contamination Monitoring in Uncontrolled Areas (RP-003-4, Rev. 2), Operation of the OCS, and noteworthy practices. Two site-specific observations and four programmatic observations were identified, none of which impacted the ability of the RAC to ensure compliance with EPA standards. In addition, one good practice observation was also identified during the audit. The overall conclusion from the audit was that the radiological program requirements of the Ambrosia Lake, New Mexico remedial action program are being satisfied according to written procedures and documentation requirements. Audit issues are outlined in Section $\mathbf{5 . 1}$ of this report.

The following observations were made during the surveillance.

Site-specific observations:

- AMB-A04-003.a - Contamination monitoring, as reviewed, is acceptable.

- AMB-A04-004.a - OCS performance, as reviewed, is acceptable.

Programmatic observations:

- APO/AMB-A04-001.a - The DOE and EPA were appropriately notified by the RAC regarding the commencement of radon flux measurements at the Ambrosia Lake UMTRA Project site.

- APO/AMB-A04-001.b - Radon flux data management, as reviewed, is acceptable. 
- APO/AMB-A04-001.c - Justification and approval of reducing radon barrier thickness is on file.

- APO/AMB-A04-002.a - Future status of RTRAK is uncertain.

Good practice observation:

- AMB-A03-NP01 - Subpart T of 40 CFR Part 61 (NESHAP)/Radon Flux Measurements (OP-003-5, Rev. 1) - Site HP personnel are performing dry runs on collecting and measuring charcoal samples to familiarize themselves with procedural requirements, as reviewed. In addition, baseline level radon flux measurements of the radon barrier will be collected prior to placement on the disposal cell.

In a letter dated 28 December 1994 (from Robert E. Cornish to Robert E. Lawrence, reference UMT/RAC/1294-0140I, the UMTRA Project Office deemed the corrective actions acceptable, thereby closing this audit.

\subsection{SUMMARY AND CONCLUSIONS}

One comprehensive radiological surveillance and three comprehensive audits were conducted in conjunction with the Ambrosia Lake, New Mexico UMTRA Project site during remedial action activities. The overall conclusion of the radiological surveillance and audits were that the health physics aspects of the remedial action program were organized and performed according to written procedures and documentation requirements. The final resolution of findings and observations in follow-up surveillances and audits and separate correspondence verified that all issues have been resolved to the satisfaction of the DOE. 


\subsection{QUALITY ASSURANCE IN-PROCESS SURVEILLANCES}

The DOE and TAC performed seven OA in-process surveillances at the Ambrosia Lake site. The in-process surveillances were performed to ensure that approved construction plans and specifications were properly implemented by the RAC. The in-process surveillances were independent of the organizations performing the work and did not relieve the RAC from its own $\mathrm{QC}$ requirements. The in-process surveillances were conducted by a team consisting of at least one TAC lead auditor and one OA representative from the DOE.

The DOE/TAC surveillance reports included observations and recommendations. Observations were comments considered appropriate by the auditors for documenting topics of concern to the DOE ERD UMTRA Project, and for noting improvements in techniques or procedures to noncritical areas. Comments on proficiency, favorable comparisons, or developmental activities were included as observations.

Recommendations were made for observations that did not meet project requirements or where a best management practice would improve work processes.

\subsection{SURVEILLANCE OBJECTIVES}

The in-process surveillances had three objectives. The first objective was to verify the RAC's compliance with the approved RAP for the Ambrosia Lake site. The surveillance team accomplished this objective by reviewing the approved Ambrosia Lake RAP and preparing checklists of key construction activities.

The second objective was to verify the RAC's compliance with approved plans and specifications. The surveillance team accomplished this by reviewing site documentation and observing construction activities from established checklists.

The third objective was to verify that the remedial action inspection plan (RAIP) was implemented. The surveillance team accomplished this objective by observing testing and inspection activities performed by the RAC's OC technicians in the field.

\subsection{SURVEILLANCE RESULTS}

A summary of results for the seven in-process surveillances performed at the Ambrosia Lake site follows.

\subsubsection{Surveillance QS93029}

This QA in-process surveillance was conducted on 7-8 June 1993, (DOE, 1993c). The surveillance team consisted of Milt Scoutaris of the DOE and Marty Alewine with the TAC. The surveillance resulted in 11 observations, one of which, observation 6 , had a recommendation that required a response from the RAC. 
Observation 6 noted that there were no requirements in the RAIP that site OC staff conduct gradation testing and uniformity coefficient $\left(C_{u}\right)$ determinations for sand-cone sand delivered to the site. The staff were not conducting these tests. The tests are required by ASTM D1556, Standard Test Method for Density of Soil in Place by the Sand-Cone Method.

The surveillance team requested that the RAC provide an explanation for omitting gradation tests and $C_{u}$ determinations, as a requirement, from the Ambrosia Lake RAIP.

The RAC responded to observation 6 on 10 August 1993. They agreed with the surveillance team's recommended requests and updated the site RAIP to include the ASTM D1556 testing requirements. A gradation test supplied by the manufacturer for previously used sand passed the ASTM gradation and $C_{u}$ requirements.

The DOE concurred with the RAC's response and closed the surveillance on 16 September 1993.

\subsubsection{Surveillance $0 \$ 93054$}

This QA in-process surveillance was conducted on 9-10 September 1993, (DOE, 1993a). The surveillance team consisted of Milt Scoutaris with the DOE and Paul Pehrson with the TAC. The surveillance resulted in 10 observations. Two observations, 7 and 8 , had recommendations that required responses from the RAC.

Observation 7 quotes a statement in the RAIP that is not present in the project specification: "Buttress and general fill materials shall be visually inspected to ensure gradation requirements of Design Specifications are satisfied. A gradation test may be performed at any time the inspector or Site Manager determines the need to physically verify gradation of the material."

The report noted that there was no gradation requirement in Specification 02200 for buttress and general fill materials. The report recommended that the statement should be removed from the RAIP or that it should be incorporated into project specifications stating what the gradation requirement is.

Observation 8 notes that daily inspection reports from 8 June 1993 to 8 September 1993, included color-coded as-built drawings that did not contain legends defining what was color-coded. The report stated that all as-built drawings should contain a legend identifying all illustrations.

The RAC responded to this report on 4 November 1993. They agreed to update the RAIP to state gradation requirements for buttress and general fill materials. They issued an interoffice correspondence to site QC supervisors on 4 November 1993 stating that legends will be included on all as-built drawings. 
The DOE concurred with the RAC's responses and closed the surveillance on 13 December 1993.

\subsubsection{Surveillance QS94125}

This QA surveillance was conducted on 6-7 April 1994 (DOE, 1994c) and resulted in 15 observations. The surveillance team consisted of Milt Scoutaris with the DOE and Paul Pehrson and Richard Papusch with the TAC. Three observations, 1, 6 and 11, had recommendations that required responses from the RAC.

Observation 1 noted that an outdated ASTM standard, ASTM C131-87 (Test Method for Resistance to Degradation of Small-Size Coarse Aggregate by Abrasion and Impact in the Los Angeles Machine), was included in the ASTM binder. The project specifications required that the 1989 version be used. This did not affect ongoing operations since rock production had not started at this time. The surveillance team recommended that the site $Q C$ supervisor contact the RAC QA manager and request that the 1989 version be forwarded to the site.

Observation 6 noted that some records between 8 November 1993 and 26 March 1994 indicated that some contaminated material was placed at above optimum moisture content. The project RAIP states that contaminated materials would be placed below optimum moisture content as determined by ASTM D698. Twenty-four percent of the tests examined exceeded the optimum moisture content. The surveillance team recommended that all areas that test above optimum moisture content be recorded on the daily inspection report. The site project manager, Don Bradley, said that he would review the data to determine if the high moisture contents resulted from excessive dust control. If this was the case, he would take corrective action.

Observation 11 noted that the drying oven used in the $\mathrm{QC}$ trailer was varying in temperature out of the $230 \pm 9$ degrees range Fahrenheit requirement. The surveillance team recommended that the RAC either fix the oven or replace it.

The RAC responded to the surveillance on 23 May 1994. They sent a copy of ASTM C131-89 to the OC department at Ambrosia Lake in response to observation 1.

In response to observation 6, a memo was issued to the Ambrosia Lake QC supervisor (James Yazzie) from the Ambrosia Lake site project manager (Don Bradley) stating that moisture addition to contaminated materials was only for environmental dust control. The memo also requested that Mr. Bradley be notified if future moisture contents tested above optimum, at which time the need for regulation of moisture addition would be considered. 
In response to observation 11 , the thermostat was replaced and the thermometer port was located from the top of the oven to "midway up the oven, away from the heating elements."

The DOE concurred with the RAC's responses and closed the surveillance on 8 July 1994.

\subsubsection{Surveillance 0 S94132}

This surveillance was conducted on 12-13 July 1994 (DOE, 1994b). The surveillance team consisted of Milt Scoutaris with the DOE and Richard Papusch with the TAC. The surveillance resulted in 18 observations, none of which had recommendations that required responses from the RAC.

The DOE closed the surveillance on 6 August 1994.

\subsubsection{Surveillance 0 S94135}

This surveillance was conducted on 18-19 August 1994 (DOE, 1994a). The surveillance team consisted of Milt Scoutaris with the DOE and Sam Wright with the TAC. The surveillance resulted in 19 observations. Five observations, 1, 9, 11,15 , and 17, had recommendations that required a response.

Observation 1 noted that field density test forms had no title, the file folder containing these tests was not labeled, and many entries were illegible. The surveillance team recommended that the test forms be titled, the file folder labeled, the illegible entries rewritten and care exercised in the future when completing the forms.

Observation 9 noted that the project inspection records did not provide documentation that radon barrier material was free of organic matter and other deleterious materiais. A site engineer had told the surveillance team that rootlets were found in the upper layer of material at the borrow site. The surveillance team recommended that the RAC record that the top layer of material with rootlets was removed before excavating radon barrier material.

Observation 11 noted that there was no specific record of stripping the top six inches of the radon barrier soil as specified in the project specifications. The engineer verbally stated that this was done. The surveillance team recommended that the stripping operation be documented.

Observation 15 noted that pages of data file number 21 were not numbered. This data file contained the results of maximum density determination results. The surveillance team recommended that the data file pages be numbered.

Observation 17 noted that the number of roller passes was not documented as required by the RAIP. The TAC recommended that this requirement be removed since field densities were confirmed with sand-cone tests. 
The RAC responded to the surveillance on 17 October 1994. The DOE concurred with the RAC's responses to observations 1, 15, and 17. The RAC responded to observation 1 by titling the field density test forms, labeling the file folder and rewriting illegible entries. The individual responsible for the illegible entries was informed to be more careful in the future.

The RAC's response to observation 15 was that the number 20 on the density test forms in question was a typographical error. A new revision of this form was issued to site personnel on 23 September 1994. These forms do not need to be numbered with page numbers.

The RAC's response to observation 17 was to revise the Ambrosia Lake RAIP to clarify the "roller passes" requirement. The new RAIP revision was Revision 3, Review C.

The DOE wrote to the RAC on 29 November 1994 that their responses to observations 9 and 11 did not fully address the recommendations. The RAC's response to observation 9 did not specifically mention the visual inspection of the excavation of top soil in the radon barrier borrow area to a depth where the material was free of visible organic material. The RAC's response to observation 11 provided a copy of a page to daily inspection report number 554 that contained a correction or addition that was not initialed and dated.

The RAC responded to the 29 November 1994 DOE letter on 21 December 1994. They provided documentation that demonstrated that radon barrier material excavation was monitored to insure that the soil was free of organic material and other deleterious substances. They stated the correction to daily inspection report 544 was made in accordance with all applicable requirements. The correction process was explained in detail in the RAC's response.

The DOE concurred with the RAC's final response and closed the surveillance in a memo to the RAC dated 25 January 1995.

\subsubsection{Surveillance OS95146}

This surveillance was conducted on 24 January 1995 (DOE, 1995c). The surveillance team consisted of Milt Scoutaris with the DOE and Richard Papusch with the TAC. The surveillance resulted in 19 observations of which observation 7 had a recommendation that required a response from the RAC.

Observation 7 noted that there was segregation apparent in Type A material placed on the top slope of the tailings embankment. The surveillance team visited the rock production quarry to see if stockpiling and loading operations could be the cause of the segregation. Segregated materials were observed in the Type A stockpiles. The surveillance team recommended that the loader operators mix the rock material before loading it into haul trucks. The team stressed that the RAC should closely monitor future loading and stockpiling 
operations for riprap materials. They also suggested that the RAC test the segregated areas to verify they are meeting the project gradation specifications.

The RAC responded to observation 7 on 2 March 1995. The RAC conducted a follow-up surveillance with $C$. Spencer, Construction Engineering Manager, and S. Martz, Quality Manager on 27 January 1995. They observed that the RAC's subcontractor had changed the load-out procedure that resulted in a more uniform, non-segregated material placement. Gradation tests performed on pockets of fine Type A materials indicated failure. The subcontractor was continuing to repair these areas to meet project specifications. Milt Scoutaris with the DOE and Steve Martz with the RAC visited the site on 13 February 1995. They observed Type B riprap placement and placed Type A riprap. They judged Type A placement to be satisfactory. These was some concern over placement of Type B riprap. Gradation tests from visually suspect Type B areas confirmed some failures. The RAC directed the subcontractor to repair these areas and continued to closely monitor loading operations at the rock quarry. Gradation tests of the reworked Type B areas passed.

The DOE concurred with the RAC's response and follow-up activities and closed the surveillance on 7 April 1995.

\subsubsection{Surveillance 0S95151}

This surveillance was conducted on 13-14 April 1995 (DOE, 1995b). The surveillance team consisted of Milt Scoutaris with the DOE and Richard Papusch with the TAC. The surveillance resulted in 16 observations. Two observations, 4 and 5 , had recommendations that required responses from the RAC.

Observation 12 contained a recommendation that did not request a response from the RAC. This observation noted that some corrections in daily inspection reports were crossed out, dated, but not initialed. The surveillance report emphasized that all corrections must be crossed out, dated, and initialed.

Both observations 4 and 5 refer to visual segregation and gradation test failures observed in Type B riprap on the south sideslope of the tailings embankment. A single recommendation was proposed by the surveillance team for both observations. The surveillance team recommended that the RAC continue to take gradation tests at Type B placement areas that display segregation.

The RAC responded to the surveillance report on 19 May 1995. They specifically responded to observation 5 . The response also covers observation 4. The RAC said that placed segregated Type B materials were continuing to be reworked. Reworking activities included replacing or reblending existing material with re-screened Type B material. Gradation testing of reworked material verified that project specifications were met.

The DOE concurred with the RAC's response and closed the surveillance on 8 July 1995. 


\subsection{SUMMARY AND CONCLUSIONS}

Seven QA in-process surveillances were conducted by the DOE and TAC at the Ambrosia Lake, New Mexico UMTRA site. The overall conclusion is that the RAC remediation construction activities were performed in compliance with the Ambrosia Lake RAP, RAIP and project specifications. The surveillances resulted in 108 observations. Fifteen observations had recommendations that required responses from the RAC. One observation had a recommendation that required no response. All recommendations that required responses were resolved and closed to the satisfaction of the DOE. All the surveillances are considered closed by the DOE. 


\subsection{REMEDIAL ACTION CLOSE-OUT INSPECTION}

The DOE/TAC conducted a final remedial action close-out inspection at the Ambrosia Lake site to ensure that remedial action was performed according to approved construction plans and specifications. The inspection was conducted on 26 July 1995 (DOE, 1995a). The DOE/TAC inspection team included Milt Scoutaris of the DOE ERD UMTRA Project and Richard Papusch of the TAC. NRC personnel present during the inspection included Ted Johnson, Tim Harris, Keith McConnell and Kenneth Hooks. The RAC's personnel included Frank Guros, James Yazzie, Ralph Waddington, Steven Martz and Karl Hamilton. The results of the final close-out inspection are documented in DOE/TAC report number QA95158.

\subsection{REMEDIAL ACTION CLOSE-OUT INSPECTION OBJECTIVES}

The objective of the remedial action close-out inspection was to determine the degree of completion of the Ambrosia Lake UMTRA Project remedial action site in accordance with the approved site construction plans and specifications. Specific site reference documents used included the latest editions of the Ambrosia Lake RAP, RAIP, design specifications, and the RAC's final walkover items from their punch list.

\subsection{REMEDIAL ACTION CLOSE-OUT INSPECTION RESULTS}

The DOE/TAC and NRC inspection teams held a short opening meeting with the RAC at the Ambrosia Lake construction office. The meeting was conducted at 10:00 AM on 26 July 1995. All TAC/DOE, NRC and RAC personnel listed above were present at the meeting. The meeting lasted for approximately 30 minutes and consisted of introductions and discussions of the RAC final walkover inspection checklist and open punch list items. The RAC checklist listed all items that were inspected and reviewed by the RAC before the date of the close-out inspection. The punch list consisted of items from the RAC checklist that needed to be completed before the final inspection is closed. The punch list items consist of the following 13 items.

Four items relating to the Long Term Surveillance Plan:

1. Complete aerial photography and mapping.

2. Repair U-bolt on sign near SM-3/BMT-3.

3. Repair sign post and replace sign on south side (mid-point).

4. Repair the Quivera mining signs with the required information.

Note: Item 4 refers to 10 perimeter sign posts on which are mounted a DOE perimeter sign and a Quivera mining restriction sign. The Quivera signs contain wording that restricts mining to within $\mathbf{4 0 0}$ feet of the site perimeter boundary. 
The 10 signs are located along the western perimeter boundary of the disposal site between permanent boundary monuments BMT-6 and BMT-7. The Quivera signs cite the Quivera name and it is not certain if this information should be on the signs.

Five items relating to the office and staging area:

5. Remove contractor trailer at Area 2.

6. Remove subcontractor trailer at Area 2.

7. The water storage tanks, waste water storage tanks and water lines, telephone lines, power poles and feeder lines, lighting poles, and gates and fence at Area 2 will remain. Need a letter from the landowner approving leaving these items in-place.

8. Remove the following items at the parking area at Area 2: garbage cans, material safety data sheet boxes, and signs (entrance and parking).

9. Remove portable chemical toilets from the site.

One item relating to site restoration:

10. Complete final grading in the Area 2 contractor office areas.

Miscellaneous:

11. Remove all survey lath and other miscellaneous trash.

Permits:

12. Storm Water Permit - Terminate at the end of the project.

13. Obtain closure letters from the owners of the radon barrier borrow.

The DOE/TAC and NRC inspection teams and the RAC performed a site walkover of the tailings embankment from 10:37 AM to 12:09 PM. The inspection teams walked up the south 5:1 side slope of the embankment and walked the top perimeter of the cell. They examined the following:

- Line and grade and gradations of the erosion protection material on the tailings embankment.

- Areas surrounding the embankment that were remediated during construction.

- Eight displacement monuments on the tailings embankment. 
- Line and grade of all erosion protection materials. Line and grade were very good and materials well keyed.

Site grading of the areas surrounding the tailings embankment was inspected during the walkover. All grading was completed and looked excellent.

The inspection teams observed the ongoing seeding operations in the areas surrounding the tailings embankment. Seeding was completed and the ongoing operations consisted of applying mulch. Seeding operations were proceeding on schedule.

The inspection teams and the RAC met back at the RAC's office trailer after the tailings embankment walkover was completed. The inspection teams examined records in the office trailer from 12:15 PM to 1:57 PM. The records checked by the inspection teams consisted of gradation records, durability tests and depth check records. The records checked by the DOE/TAC were records that were not examined during previous surveillances.

All records examined by the DOE/TAC and NRC passed project requirements. Tim Harris of the NRC was given a demonstration of the RAC's geotechnical software package for proctor testing by Steve Martz and James Yazzie.

The NRC held a close-out meeting in the RAC's office trailer at 1:57 PM. Everyone listed in the introduction was present. The meeting was brief and the NRC mentioned that they found no findings during the site walkover and examination of records. They commended the RAC on a job well done before closing the meeting. All NRC personnel left the site after the close-out meeting.

James Yazzie took the DOE/TAC inspection team on a drive around the tailings embankment from 2:00 PM to 3:15 PM. The inspection team examined the permanent survey/boundary and boundary monuments, the entrance sign, perimeter signs, site markers and the project survey control point. They counted perimeter signs and noted there were 70 signs placed 200 feet apart as required by project specifications.

The DOE/TAC held a close-out meeting with the RAC at 3:15 PM. Everyone listed in the introduction, excluding NRC personnel, was present. Items discussed included the following:

- One durability record, DUR-C-01, was not yet approved and placed in the RAC's files. It was decided that this record would be checked by Richard Papusch of the TAC in Albuquerque, NM.

- Was there a 180 day requirement to check if seeding takes hold? James Yazzie and Steve Martz showed the DOE/TAC team the project specification that indicated there was no 180 day requirement for the Ambrosia Lake, New Mexico site. The seeding specification, Section 
02935 of the project specifications, states: "The Subcontractor shall be responsible for caring for seeded areas, as required, and in accordance with the written recommendations of the SCS [U.S. Soil Conservation Service] until adequate vegetative cover is established."

- Richard Papusch noted that the displacement monuments on the tailings embankment were not locked or marked with identification. Karl Hamilton said that the RAC would acquire locks for, and permanently mark, the displacement monuments.

- The DOEITAC team and the RAC discussed if the Quivera name will be removed from the mining restriction signs. The RAC said they were in contact with Quivera to settle this.

The DOE/TAC team congratulated the RAC on a job well done and closed the meeting at 4:00 PM.

\subsection{SUMMARY AND CONCLUSIONS}

The DOE did not consider the final remedial action close-out inspection closed until MK-Ferguson addressed the 13 open items listed on their final walkover inspection punch list. MK-Ferguson responded to the 13 open items on their punch list on 8 September 1995. The DOE concurred with their responses and closed the final close-out inspection on 14 September 1995. 


\subsection{OTHER AUDITS AND CONSTRUCTION REVIEWS}

\subsection{ON-SITE CONSTRUCTION REVIEW OBJECTIVES}

This section covers OSCRs performed by the NRC and other site related construction audits. The NRC did not perform any OSCRs during construction of the Ambrosia Lake tailings embankment. The NRC visited the site during the final remedial action close-out inspection (see Section 4.0). No other site related construction audits, excepting the RAC's internal audits, were conducted at the Ambrosia Lake site. The RAC's site-related audits are referenced in the Ambrosia Lake Completion Report. 


\subsection{SUMMARY AND CONCLUSIONS}

One radiological surveillance, three radiological audits, seven QA in-process surveillances, and one remedial action close-out inspection were conducted by the DOE/TAC staff during remedial action construction activities at the Ambrosia Lake, New Mexico, UMTRA site. A total of 155 observations were noted during DOE/TAC audit and surveillance activities. Follow-up to responses required from the RAC for the DOE/TAC surveillance and audit observations indicated that all issues related to the Ambrosia Lake site were resolved and closed to the satisfaction of the DOE. The 13 open items on the MK-Ferguson punch list for the final close-out inspection were adequately addressed by MK-Ferguson. The DOE subsequently closed the final close-out inspection.

All audit and surveillance observations and recommendations have been closed out to the DOE's satisfaction. Therefore, this final audit report segment of the site certification process is complete. 


\subsection{LIST OF CONTRIBUTORS}

The following individuals contributed to the preparation of this report.

\begin{tabular}{ll}
\hline Name & Contribution \\
\hline M. B. Leaf & Document sponsor \\
R. Papusch & Document coordinator \\
R. Papusch, J. Hylko & Primary authors \\
P. Pehrson, M.B. Leaf & Document review \\
D. Kahl & Technical editing \\
L. Sanchez, PWS-CCS & Text processing \\
\hline
\end{tabular}




\subsection{REFERENCES}

DOE (U.S. Department of Energy), 1995a. Report of Remedial Action Close-Out Inspection of the MK-Ferguson Company Remedial Action Construction, UMTRA Project, Ambrosia Lake, New Mexico, July 26, 1995, Report No. QA95158, prepared by the U.S. Department of Energy Environmental Restoration Division, UMTRA Project Team, Albuquerque, New Mexico, UPDCC file location No. 16.13.2.3, August 2, 1995.

DOE (U.S. Department of Energy), 1995b. Report of Quality Assurance Surveillance of the MK-Ferguson Company Remedial Action Construction, UMTRA Project, Ambrosia Lake, New Mexico, April 13-14, 1995, Report No. QS95151, prepared by the U.S. Department of Energy, UMTRA Project Office, Albuquerque, New Mexico, UPDCC file location No. 16.29.3.2, April 17-20, 1995.

DOE (U.S. Department of Energy), 1995c. Report of Quality Assurance Surveillance of the MK-Ferguson Company Remedial Action Construction, UMTRA Project, Ambrosia Lake, New Mexico, January 24, 1995, Report No. QS95146, prepared by the U.S. Department of Energy, UMTRA Project Office, Albuquerque, New Mexico, UPDCC file location No. 16.29.3.2, January 26-31, 1995.

DOE (U.S. Department of Energy), 1994a. Report of Quality Assurance Surveillance of MK-Ferguson Company Remedial Action Construction, UMTRA Project, Ambrosia Lake, New Mexico, August 18-19, 1994, Report No. OS94135, prepared by the U.S. Department of Energy, UMTRA Project Office, Albuquerque, New Mexico, UPDCC file location No. 16.29.3.2, September 15-20, 1994.

DOE (U.S. Department of Energy), 1994b. Report of Quality Assurance Surveillance of MK-Ferguson Company Remedial Action Construction, UMTRA Project, Ambrosia Lake, New Mexico, July 12-13, 1994, Report No. OS94132, prepared by the U.S. Department of Energy, UMTRA Project Office, Albuquerque, New Mexico, UPDCC file location No. 16.29.3.2, July 25 - August 1, 1994.

DOE (U.S. Department of Energy), 1994c. Report of Quality Assurance Surveillance of MK-Ferguson Company Remedial Action Construction, UMTRA Project, Ambrosia Lake, New Mexico, April 6-7, 1994, Report No. QS94125, prepared by the U.S. Department of Energy, UMTRA Project Office, Albuquerque, New Mexico, UPDCC file location No. 16.29.3.2, April 14-24, 1994.

DOE (U.S. Department of Energy), 1994d. Radiological Audit of Remedial Action Activities at the Processing Site, Ambrosia Lake, New Mexico, March 21-23 and August 1-2,1994, Reports $A M B-A 03$ and $A M B-A 04$, prepared by the U.S. Department of Energy, UMTRA Project Office, Albuquerque, New Mexico, UPDCC file location No. 16.18.5. 
DOE (U.S. Department of Energy), 1993a. Report of Quality Assurance Surveillance of MK-Ferguson Company Remedial Action Construction, UMTRA Project, Ambrosia Lake, New Mexico, September 9-10, 1993, Report No. QS93054, prepared by the U.S. Department of Energy, UMTRA Project Office, Albuquerque, New Mexico, UPDCC file location No. 16.29.3.2.

DOE (U.S. Department of Energyl, 1993b. Radiological Audit of Remedial Action Activities at the Processing Site, Ambrosia Lake, New Mexico, July 26-29, 1993, report AMB-A02, prepared for the U.S. Department of Energy, UMTRA Project Office, by Jacobs Engineering Group Inc., Albuquerque, New Mexico, UPDCC file location No. 16.18.5, August 1993.

DOE (U.S. Department of Energy), 1993c. Report of Quality Assurance Surveillance of MK-Ferguson Company Remedial Action Construction, UMTRA Project, Ambrosia Lake, New Mexico, June 7-8, 1993, Report No. QS93029, prepared by the U.S. Department of Energy, UMTRA Project Office, Albuquerque, New Mexico, UPDCC file location No. 16.29.3.2, June 11, 1993.

DOE (U.S. Department of Energyl, 1993d. Radiological Surveillance of Remedial Action Activities at the Processing Site, Ambrosia Lake, New Mexico, April 12-16, 1993, report $A M B$-SO1, prepared for the U.S. Department of Energy, UMTRA Project Office, by Jacobs Engineering Group Inc., Albuquerque, New Mexico, UPDCC file location No. 16.18.5, April 1993.

DOE (U.S. Department of Energy), 1988. UMTRA Project Audit/Surveillance Program Plan, UMTRA-DOE/AL-400326.0000, DOE UMTRA Project Office, Albuquerque Operations Office, Albuquerque, New Mexico.

\section{CODE OF FEDERAL REGULATIONS}

40 CFR Part 61, National Emission Standards for Hazardous Air Pollutants, U.S. Environmental Protection Agency (1985).

40 CFR Part 192, Health and Environmental Protection Standards for Uranium and Thorium Mill Tailings, U.S. Environmental Protection Agency (1991).

\section{FEDERAL REGISTER}

60 FR 2854, EPA's Final Standards for Remedial Action at Inactive Uranium Processing Sites with Groundwater Contamination, U.S. Environmental Protection Agency, January 11, 1995.

\section{UNITED STATES CODE}

42 USC $\$ 7901$ et seq., Uranium Mill Tailings Radiation Control Act, November 8, 1978. 